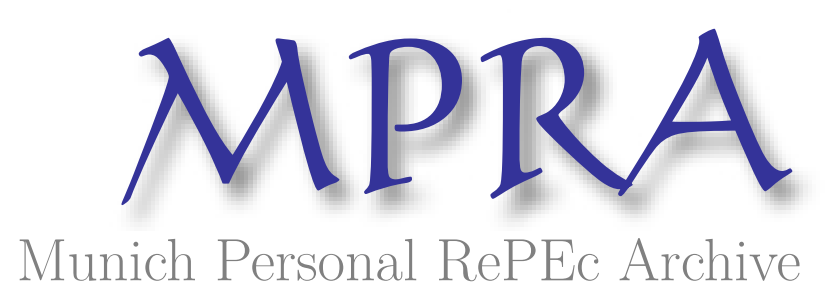

\title{
The Effects of Discretionary Fiscal Policy on Macroeconomic Aggregates: A Reappraisal
}

Hebous, Shafik

Goethe University Frankfurt

July 2009

Online at https://mpra.ub.uni-muenchen.de/23300/

MPRA Paper No. 23300, posted 14 Jun 2010 21:30 UTC 


\title{
The Effects of Discretionary Fiscal Policy on Macroeconomic Aggregates: A Reappraisal
}

\author{
Shafik Hebous* \\ Goethe University Frankfurt
}

First version July 2009

This version June 2010

\begin{abstract}
Fiscal stimuli to recover? A cascade of academic and layman-articles debate the effectiveness of fiscal policy in stimulating the economy backed up by different economic models and empirical support. This essay surveys the theoretical predictions and recent empirical Vector Autoregression (VAR) evidence on the short-run effects of discretionary fiscal policy on macroeconomic aggregates.
\end{abstract}

Keywords: Macroeconomic Policy, Fiscal Policy, Multipliers, Fiscal Stimulus, VAR JEL Code: E620, H300, H600

\footnotetext{
* Goethe University Frankfurt, Grüneburgplatz 1, Hauspostfach 45, 60323 Frankfurt / Germany; email: hebous@wiwi.uni-frankfurt.de. I thank Michael P. Devereux, Alfons Weichenrieder, Tom Zimmermann, and two anonymous referees for helpful suggestions and comments. The usual disclaimer applies.
} 


\section{Introduction}

The effectiveness of fiscal policy in stimulating the real economy has been an active intellectual debate in academic journals and high profile columns at least since Keynes wrote his General Theory. Can an expansionary fiscal policy, an increase in government spending or a tax cut, boost output and consumption? If yes, by how much? These are not only key questions in macroeconomics and public finance but also questions that frequently confront policy makers. The recent fiscal stimulus packages embraced by many leading economies are deemed of as a necessary prescription to assuage the consequences of the current global economic slowdown (IMF Staff Note Position 2008; 2009). The environment of low interest rate close to the zero bound further heats the discussion.

Economic theory has offered more than one prediction depending on the characteristics of the economy under consideration: Is it a "Neo-classical" or "Keynesian" world? Are consumers "Ricardian" or "non-Ricardian"? Is it a closed or an open economy? Modern dynamic stochastic general equilibrium models have different implications than standard Keynesian theory. Answers differ not only with respect to the size of the effect but also in some cases with respect to the direction of the effect. The theoretical debate seems not to reach a consensus due to a lack of persuasive empirical evidence. Econometric studies, employing Vector Autoregression (VAR) analysis, have offered mixed support. The crucial difficulty with this regard is the identification of the effects of the change in fiscal policy isolating all other effects.

This essay surveys the literature, the theoretical strand and recent econometric (VAR) findings, on the short-run effects of discretionary fiscal policy on macroeconomic aggregates. The main theme of this survey is that the recent advances in economic modelling and econometric techniques do not, thus far, completely resolve the protracted debate on the size of the multiplier and qualitative response of consumption, the real exchange rate and other key variables.

Undoubtedly, discussing fiscal policy involves many important aspects that are beyond the scope of this essay. Examples are the sustainability of fiscal policy, Wickens (2008, chapter 5) and Uctum and Wickens (2000), the intergenerational aspect of the public debt burden, Auerbach (2009), and the role of automatic stabilisers (i.e. the propensity of some components of the government budget such as corporate taxes and unemployment benefits to smooth the business cycle), Auerbach and Freenberg (2000) and van den Noord (2000).

This essay proceeds as follows. Section two provides an overview of the predictions of economic theory on the effects of a fiscal policy shift on key macroeconomic variables. Section three summarises recent econometric methodologies and findings while section four concludes.

\section{Theoretical overview}

In examining the transmission mechanism of fiscal policy one crucial assumption of any model is whether or not agents are forward looking. In the absence of micro-founded forward looking behaviour, expected future changes have no effects on current period decisions whereas forward looking consumers, armed with rational expectations, do react in the current period to expected changes in future variables. The following two subsections provide an overview of theoretical predictions distinguishing between models with and without a micro-founded forward looking behaviour.

\subsection{Theories without micro-founded forward looking behaviour}

In the Classical model in which prices are fully flexible and the supply curve is vertical, there is no role for fiscal policy. In the other boundary world, the Keynesian model, illustrated by the undergraduate IS-LM and Mundell-Fleming analyses, prices are sticky and current consumption depends on current income with no role for expected future income. In this world, an expansionary fiscal policy can stimulate the economy with multiple effects. The mechanism by which these effects occur depends on the degree of openness and the embraced exchange rate regime of the economy. 
In a closed economy, for a given money supply, an increase in government spending stimulates economic activity increasing output. Since money demand depends on income, the increase in output raises the interest rate, which in turns partially crowds out private investment. The degree of crowding out depends on the sensitivity of private investment to income and the interest rate. The final effect of the expansion is an increase in output, total investment and consumption. A fiscal expansion in the form of a tax cut boosts private consumption leading to an increase in aggregate demand and output. Also in this case, like the expansion of government spending, the resulting increase in the interest rate partially crowds out private investment. Hence, the effects of a tax cut are qualitatively the same as the increase in government spending. The tax multiplier however is smaller than the government-spending multiplier since a part of the increase in disposable income will be saved and not directly spent.

In a small open economy with a flexible exchange rate regime, a fiscal expansion puts upward pressure on the interest rate. If capital is perfectly mobile and the interest rate is fixed at the world level, capital flows into the economy increasing the demand for the domestic currency. As a result, the nominal exchange rate appreciates. Because prices are sticky, the nominal appreciation is mapped to a real exchange rate appreciation. Consequently, net exports decline. This negative effect on the trade balance offsets the expansionary effect of fiscal policy. Thus, according to this setting, fiscal policy in small open economies with a flexible exchange rate regime is ineffective. While a small open economy cannot affect the rest of the world, the case of a large open economy lies between the two polar cases of a closed and a small open economy. In an open economy with a fixed exchange rate regime, fiscal expansion puts upward pressure on the exchange rate and interest rate. Money supply increases to defend the fixed exchange rate parity. The final effect is an increase in output. Hence, fiscal policy under this scenario is effective in stimulating output.

In an integrated world, domestic fiscal policy can affect foreign economies, particularly in the case of a currency union; i.e. a multi-country Mundell-Fleming model with a fixed exchange rate regime. Fiscal policy externalities may arise in opposite directions. The increase in domestic output will lead to additional imports from trading partners boosting the income of the trading partners (trade channel). At the same time, the initial upward pressure on the domestic interest rate attracts foreign capital including capital from other members of the currency union. Hence, members' interest rates are under upward pressure. As a result, the union-wide interest rate may rise. This in turns has a contractionary effect on output (interest rate channel). Additionally, the exchange rate of the union currency is floating with the rest of the world. If the fiscal expansion in a (large) member economy causes an appreciation to the real exchange rate with the rest of the world, as the Mundell-Flemming model predicts, the expansionary effects will be dampened due to worsening trade balance. Yet, the theoretical reasoning assumes that one country implements a fiscal stimulus plan, possibly in response to a country-specific negative shock, while ignoring the policy of the rest of the world. In an environment of an international economic downturn (a common global shock), one might argue in favour of a collective fiscal effort. As mentioned above, the effects of fiscal stimuli in highly open economies can be retarded by the appreciation of the real exchange rate and the deterioration of the trade balance. Coordinated fiscal actions among trading partners can reduce the bill of the countryspecific fiscal stimulus and eliminate free-riding possibilities. ${ }^{1}$

\subsection{Theories with micro-founded forward looking behaviour}

The analysis presented in the previous section is not based on micro-founded behaviours. Macroeconomic theory is increasingly building on Dynamic Stochastic General Equilibrium (DSGE) models to derive micro-founded intertemporal aggregate relations that explain the factors behind economic fluctuations. Typically, DSGE models incorporate forward looking agents and rational expectations. The modelling strategy is as follows: All agents in the model follow optimal plans. Consumers maximise lifetime expected utility subject to the budget constraint. Firms maximise profits subject to the available technology, and the government has to satisfy the government budget constraint. To solve the model, usually, the resulting optimisation conditions together with the equilibrium conditions are linearised around the steady state (perturbation). ${ }^{2}$ The final solution of the

\footnotetext{
${ }^{1}$ See IMF Staff Note Position 2008.

${ }^{2}$ Some models are closed by solving the non-linear system (projection).
} 
model can be summarised by a set of linear equations. The economy in these models is subject to stochastic disturbances, which are named "shocks". A disturbance to a fiscal variable, government spending or taxes, is a fiscal shock. In order to study the dynamics of the variables following a shock, the model' parameters are calibrated and/or estimated. Calibration means assigning values for the parameters based on microeconometric evidence or theoretical justifications.

Two important assumptions distinguish between two types of DSGE models: The Real Business Cycle (RBC) model in which prices are flexible and perfect competition prevails in all markets and the New Keynesian (NK) models with sticky prices and imperfect competition. The following two subsections survey the role of fiscal policy in both types of models. The setup and solution techniques of DSGE models can be found in details in DeJong and Dave (2007), Galí (2008), McCandless (2008) and Woodford (2003).

\subsubsection{Fiscal policy in Real Business Cycle models}

RBC models primarily focus on the role of real shocks, such as technology and preferences shocks, in explaining economic fluctuations. Rebelo (2005) presents an overview of RBC models. The analysis of fiscal policy in a RBC setup can be found for examples in Baxter and King (1992), Burnside, Eichenbaum and Fisher (2004), Christiano and Eichenbaum (1992), Edelberg, Eichenbaum and Fisher (1999) and Ohanian (1997).

In a prototypical $\mathrm{RBC}$ model, government spending is financed by lump-sum taxes. The forward looking consumer understands that additional government purchases in the current period have to be financed by taxes in the future. Therefore, an increase in government spending reduces the household wealth by increasing the present value of household tax liabilities (negative wealth effect). As a result, consumption declines while interest rate, saving and labour supply increase. The rise in hours worked in turn causes real wages to fall whereas investment and output increase. This described fiscal policy transmission is in force whether the rise in government spending is permanent or persistent but not permanent; Burnside, Eichenbaum and Fisher (2004). The intuition behind the increase in investment is that the higher steady state level of hours worked requires initially higher investment to build up additional capital stock; Edelberg, Eichenbaum and Fisher (1999). If the increase in government spending is very temporarily, investment goes down to smooth consumption.

The response of private consumption to the increase in government spending is independent of the financing tool. Permanent income is the same with a tax-financed or a debt-financed expansion; i.e. Ricardian equivalence holds. Burnside et al. (2004) show that the effects of distortionary taxes are qualitatively and quantitatively similar to the effects of lump-sum taxes except for some differences concerning the timing of the peak response. Further, in a modified version of the model, Burnside et al. (2004) introduce investment adjustment costs and habit persistence in private consumption. ${ }^{3}$ This modified version of the model mutes, but not completely, the negative effect of the shock on consumption and generates a hump shaped response for investment.

The classical open economy treatment of RBC models by Backus, Kehoe and Kydland (1994) focuses on the dynamics of the terms-of-trade and the trade balance following a technology shock. Other studies are mainly concerned with the implied properties of the international business cycle and correlation patterns between key variables. Cardia (1991) finds a very small role of fiscal shocks in explaining output volatility in a small open economy.

Thus, in contrast to the Keynesian prediction, $\mathrm{RBC}$ models predict a negative effect of fiscal expansion on consumption, albeit a positive effect on output.

\subsubsection{Fiscal policy in Neo-Keynesian (NK) models}

The NK DSGE framework adopts the RBC modelling strategy of deriving micro-founded aggregate relations, but fundamentally differs in assuming monopolistic competition and nominal rigidities. A

\footnotetext{
${ }^{3}$ Habit persistence in consumption states that consumers do not derive utility from the level of consumption but rather from relative consumption. If the period utility function without habit persistence is $u\left(C_{t}\right)$ where $C_{t}$ is consumption in period $t$, habit persistence implies a period utility function of the form $u\left(C_{\mathrm{t}}-a C_{\mathrm{t}-1}\right)$ where the parameter " $a$ " captures the intensity of habit persistence. See Ravn, Schmitt-Grohé and Uribe (2008) for an overview of different formations of habit persistence.
} 
particular interest of this class of models is the study of monetary policy; Christiano, Eichenbaum and Evans (2005) and Smets and Wouters (2003).

Analysing fiscal policy in a standard NK DSGE model generally gives similar predictions to those of a prototypical RBC model: an increase in output and a decrease in consumption; Linnemann and Schabert (2003). This is due to the negative wealth effect of a fiscal expansion resulting from the embedded forward looking behaviour of households in both types of models. The labour market reacts differently, though. As stressed by Pappa (2009a), in contrast to the RBC prediction, real wages in a NK model increase after a positive shock to government consumption. This is because the resulting increase in output raises the demand for labour which in a NK setup offsets the increase in the labour supply due to the negative wealth effect.

Many NK DSGE models do not include capital (short-run models), and therefore refrain from fully modelling private investment decisions. In models with capital accumulation, an increase in government spending raises the interest rate and crowds out private investment. Christiano, Eichenbaum and Rebelo (2009) show that when the zero bound of the nominal interest rate is strictly binding, the positive effect of an increase in government spending on output raises expected inflation. This in turn causes a decline in the real interest rate. In such economy, the government spending multiplier is relatively large.

Thus, in its simplest form, a NK DSGE model misses the Keynesian prediction of a positive effect of a fiscal expansion on consumption. Furthermore, Monacelli and Perotti (forthcoming) show that an increase in government spending in a standard open economy DSGE model typically causes an appreciation of the real exchange rate and worsens the trade balance. As it is revealed in the next section however, there are empirical studies that report a positive impact on consumption coupled with a depreciation of the real exchange rate. Hence, many studies are apt to modify prototypical DSGE models particularly due to the responses of consumption and the real exchange rate. As regards fiscal policy externalities in a DSGE setup, Corsetti, Meier and Müller (2010) show in a two-country DSGE model that financing a fiscal expansion with a combination of an increase in taxes and a decrease in government spending in the medium-run enhances positive cross-border fiscal spillovers.

\subsection{The consumption controversy}

Broadly, there are four main modifications to DSGE models in order to get the Neo-Keynesian predictions in line with the Keynesian, and the RBC predictions in line with influential econometric evidence; that is generating a positive response of consumption.

First, some models adopt a non-separable utility function in consumption and leisure. Linnemann (2006) applies this strategy in a RBC setup. This specification of preferences implies that consumption and leisure are substitutes. The negative wealth effect of the fiscal expansion raises hours worked, which decreases leisure. Consequently, the marginal utility of consumption increases. The household wants to work more and to consume more mitigating the negative wealth effect. As a result, in this model consumption, employment and output increase. However, as emphasised by Bilbiie (2009), the non-separable utility specification has the drawback that consumption increases only if it is an inferior good.

A second method of generating a positive effect on consumption is to introduce habit persistence in consumption at the good level (so-called "deep habits"); Ravn, Schmitt-Grohé and Uribe (2006). Although this model does not include nominal rigidities, it departs from the standard RBC model by assuming monopolistic competition in goods markets. In this model, the mark-up of price over the marginal cost inversely depends on the price elasticity of demand, which is in the presence of deep habits related to aggregate demand. The spending shock stimulates aggregate demand and labour supply. Firms reduce the mark-ups and increase labour demand. The increase in labour demand over-offsets the increase in labour supply. Real wages rise. The value of leisure in terms of consumption declines. The final effect is an increase in output and consumption. Time variant mark-ups are the driving engine of the positive effect on consumption in the presence of deep habits. In a standard DSGE model, mark-ups are time invariant. Closely linked to the contribution of Ravn et al. (2006) is the study by Bouakez and Rebei (2007) who allow households' preferences in a RBC model to exhibit habit persistence in consumption and to depend on government spending. In this model, the marginal utility of consumption increases after a government spending shock because private and public spending are complements. 
Third, some NK DSGE models include two types of households: Ricardian households and "rule-of-thumb" (or non-Ricardian) households who consume all of their current income; Coenen and Straub (2005) and Galí, Vallés and López-Salido (2007). This idea traces back to Campbell and Mankiw (1989) and Mankiw (2000). A non-Ricardian consumer can be deemed of as either a consumer who faces a binding borrowing constraint or an irrational consumer. In these models, the increase in real wages resulting from the positive shock to government spending leads the nonRicardian households to increase their consumption. Depending on the share of the non-Ricardian households in total households, the effect on aggregate consumption can be positive. For instance, Coenen and Straub (2005) and Forni, Monteforte and Sessa (2009) estimate this share in the Euro Area to be lower than 25 percent and between 30 and 40 percent, respectively. Campbell and Mankiw (1989) find that half of income in the US goes to rule-of-thumb consumers.

Fourth, as argued by Corsetti, Meier and Müller (2009) an increase in current government spending may not only lead to an increase in future taxes but also to a decrease in future government spending (spending reversals). This spending reversal effect is modelled by allowing the dynamics of government spending to respond to the stock of public debt. Additionally, Corsetti et al. (2009) allow for non-Ricardian consumers. In this model, a fiscal shock coupled with anticipated spending reversal in a sticky price world increases output and consumption.

\subsection{The real exchange rate controversy}

In contrast to the findings of some econometric studies, Keynesian and DSGE models predict an appreciation of the real exchange rate following the fiscal expansion. A theoretical model that predicts the opposite is Obstfeld and Rogoff (1995). In their two-country intertemporal model, the standard negative wealth effect on consumption does hold. As a result, an increase in government spending decreases the relative demand for domestic money and raises domestic prices. The purchasing power parity implies a depreciation of the nominal exchange rate.

Monacelli and Perotti (forthcoming) however argue, based on econometric evidence, that the depreciation of the exchange rate must be associated with an increase and not a decrease in consumption. This result can be achieved by adopting non-separable preferences or the deep habit persistence (time variant mark-ups). Ravn et al. (2007) show in a model of deep habits that an anticipated government spending shock, on impact, decreases consumption and causes an appreciation of the real exchange rate, as in standard DSGE models, whereas an unanticipated government spending shock increases consumption and causes a depreciation of the real exchange rate.

Monacelli and Perotti (forthcmoing) point out that the behaviour of non-Ricardian consumers does not determine the real exchange rate. Therefore, the inclusion of non-Ricardian consumers per se, although it generates a positive effect on consumption, does not generate a depreciation of the real exchange rate. In the spending reversal model of Corsetti, Meier and Müller (2009), the real exchange rate does depreciate while consumption increases after a fiscal expansion.

Concerning other indicators of relative prices, Müller (2008) shows that in the presence of home bias in private and government consumption a government spending shock leads to an appreciation in the terms-of-trade (the relative price of imports). Additionally, net exports will increase if some elasticity conditions hold. In principle, home bias in consumption is the assumption behind the change in relative prices. Without a home bias, a change in consumption will not change relative prices and the terms-of-trade.

Further, Monacelli and Perotti (2008) examine the response of the relative price of non-traded goods. Intuitively, if government consumption is more intensive in services (i.e. intensive in nontraded goods) than private consumption is, an increase in government spending leads to an appreciation of the price of non-traded goods. Monacelli and Perotti (2008) show that the openness of the economy to international trade implies an increase in the price of non-traded goods after a government spending shock even if government spending is not more intensive in non-traded goods than private consumption is.

The link between the budget balance and the current account, ultimately based on the national account identity, is frequently cited as the "twin deficit" hypothesis according to which an increase in 
the budget deficit worsens the current account. ${ }^{4}$ Corsetti and Müller (2006) stress the role of openness to international trade in the reaction of domestic saving, investment, and hence the current account to changes in fiscal policy. Corsetti and Müller (2006) argue that a negative shock to the budget deficit worsens the current account only in rather open economies. Empirical support for the twin deficit hypothesis is reviewed in section three.

\subsection{Fiscal policy rules}

While the focus here is discretionary fiscal policy, there is a strand of literature that examines "optimal" fiscal policy rules. Reviewing this literature in details is beyond the scope of this essay. In essence, fiscal policy can be thought of as the commitment of fiscal authority to follow a certain rule. For example, Taylor (2000) presents a rule that expresses the actual fiscal balance as a function of output gap and structural fiscal balance. Committing to a fiscal rule implies that fiscal policy "automatically" responds to the state of the economy. A fiscal shock is a disturbance to the fiscal rule. The "optimal" rule is the rule that maximises the model's welfare function. Additionally, in the presence of nominal rigidities, it is important to take into account the reaction of the monetary authority to fiscal policy. Accommodating monetary policy reduces the expansionary effects of fiscal policy. The DSGE literature is rich of studies that model the interaction of endogenously derived or exogenously assumed fiscal and monetary policy rules; for instance Schmitt-Grohé and Uribe (2007) and Adam and Billi (2008). Further, some studies derive the optimal policy mix particularly for a currency union; for example Beetsma and Jensen (2005), Galí and Monacelli (2008) and Ferreo (2009).

\subsection{Departing from the infinite horizon representative agent models}

The transmission mechanism of fiscal shocks may differ if we depart from modelling fiscal policy within the infinite horizon representative agent DSGE framework and consider instead a demographic structure of the economy. For example, when consumers have finite horizons the effects of a fiscal expansion depends on consumers' perceptions of the timing of the expected increase in future taxes (stabilisation programs). In the model of Sutherland (1998), at a low level of public debt the expected increase in taxes due to a current fiscal expansion is remote for the current generation allowing for short-run Keynesian expansionary effects. However, in the case of a fiscal expansion at a high level of public debt, current consumers expect an imminent increase in taxes within their lifetimes. Therefore, the fiscal expansion in this situation has a contractionary effect. A similar non-Keynesian effect is advocated by the hypothesis of "expansionary fiscal contraction" modelled by Devereux (2003) and Barry and Devereux (2005). According to this hypothesis, a credible permanent reduction in government consumption reduces expected future tax liabilities. Consumers in the current generation increase current consumption by less than future consumption. The real interest rate falls leading to higher levels of investment and output in the steady state.

Despite the possibility of a non-Keynesian effect of fiscal policy, a Keynesian effect still can be found in models that combine demographic effects with market imperfections. For example, Ganelli (2007) and Ganelli (2005) consider overlapping generation models with sticky prices in a closed economy and an open economy setup respectively. Since the Ricardian equivalence does not hold in these models, a debt-financed tax cut increases households' wealth boosting private consumption and causing an appreciation of the real exchange rate in the short-run. Further, Farmer (forthcoming) derives a multi-generations micro-founded Keynesian model in which self-fulfilling loss of confidence in the value of assets lowers output and employment. In this model, an increase in government spending restores full employment and shifts the economy to a new equilibrium with a higher real interest rate and a higher income, but this stimulus is costly to future generations who incur higher taxes.

\footnotetext{
${ }^{4}$ Recall the identity: $C A=(S-I)+(T-G)$, which states that that the current account $(C A)$ is equal to the sum of two components: private saving and primary budget surplus.
} 


\subsection{Summary of theoretical predictions}

The upshot of the theoretical overview presented in this section is roughly displayed in table (1). Most theoretical macroeconomic models agree on the positive effect of an expansionary fiscal policy on output. The responses of consumption, real wages, hours worked and the real exchange rate are model dependent. Theoretical models disagree on the qualitative responses of these variables. Standard DSGE models predict a negative effect on consumption contrary to the Keynesian model. Real wages increase on impact in NK DSGE models but decrease in RBC models. Typically, in a DSGE framework, the real exchange rate appreciates and the trade balance worsens.

Several modelling strategies are implemented in a DSGE setup in order to generate a positive effect on consumption and/or a depreciation of the real exchange rate following a fiscal expansion. Essentially, these efforts build on the standard DSGE framework and alter the model by either modifying preferences, adopting non-separable utility or deep habits, or introducing two types of households: Ricardian and non-Ricardian, or allowing future government spending to decrease as a tool to reduce public debt (spending reversals).

Table (1) Theoretical predictions on the qualitative response of key variables

\begin{tabular}{|c|c|c|c|c|c|c|c|c|c|}
\hline & $Y$ & $C$ & $L^{\mathrm{d}}$ & $L^{\mathrm{s}}$ & $\begin{array}{l}\text { Real } \\
\text { wage }\end{array}$ & $\begin{array}{l}\text { Interest } \\
\text { rate }\end{array}$ & $\begin{array}{c}\text { Private } \\
\text { investment }\end{array}$ & $\begin{array}{c}\text { Trade } \\
\text { balance }\end{array}$ & $\begin{array}{c}\text { Real } \\
\text { exchange } \\
\text { rate }\end{array}$ \\
\hline Keynesian: closed economy & + & + & $+*$ & + & - & + & - & & \\
\hline Keynesian: flexible exchange rate & $=$ & + & $=$ & $=$ & $=$ & $=$ & $=$ & - & + \\
\hline Keynesian: fixed exchange rate & + & + & + & + & - & $=$ & $=$ & $=$ & $=$ \\
\hline Real business cycle & + & - & $=$ & + & - & + & + & - & + \\
\hline New Keynesian & + & - & + & + & + & + & - & - & + \\
\hline Separable utility & + & + & $=$ & + & - & + & - & - & - \\
\hline Deep habits & + & + & + & + & + & $=* *$ & - & - & - \\
\hline Spending reversals & + & + & + & + & + & + & $* * *$ & - & - \\
\hline
\end{tabular}

Note: The sign "+" indicates a positive effect and in the case of the real exchange rate an appreciation whereas the sign "." indicates a negative effect and in the case of the real exchange rate a depreciation. The sign "=" indicates no effect.

* While the Keynesian model is mute on the exact transmission mechanism that occurs in the labour market following a fiscal expansion, according to the Neo-Keynesian interpretation, firms demand labour up to the point where the marginal product of labour equals the real wage. The expansionary effect increases prices, reduces real wages. Hence, firms hire more labour.

** The papers of Ravn et al. $(2006 ; 2008)$ do not report the impulse response of the real interest rate to a government spending shock. Zubairy (2009) presents an estimated DSGE deep habits model in which the response of the interest rate is insignificant and indistinguishable from zero.

*** The model of Corsetti et al. (2009) does not explicitly include private investment decisions.

\section{Empirical methodologies and findings}

As presented in the previous section, economic theory has left some key issues for empirical clarification, mainly the sizes of the effects, especially on output (the multiplier), and the qualitative response of other key variables such as consumption and the real exchange rate. Studying the dynamics of macroeconomic variables after a fiscal policy shock is increasingly accomplished by employing Vector Autoregression (VAR) models. Stock and Watson (2001) provide an accessible overview and Lütkepohl (2005) gives a detailed explanation of the VAR approach. This section presents a brief description of the treatment of fiscal policy in VAR studies and summarises recent empirical findings.

\subsection{Fiscal policy in VAR models}

A reduced VAR model takes the following form: 


$$
X_{t}=\sum_{i=1}^{k} M_{i} X_{t-i}+e_{t}
$$

where the $n$-dimensional vector $X$ includes the endogenous variables of interest. $M_{i}$ is the $n \times n$ matrix of coefficients. The optimal number of included lags $k$ can be determined by some information criteria such as the Akaike or Schwarz criterion. The vector of reduced form residuals $e_{t}$ is $n$-dimensional with the variance-covariance matrix $\Sigma_{e}$, where $E\left[e_{t} e_{t}^{\prime}\right]=0$. Earlier VAR studies, for example Blanchard and Perotti (2002), employ a 3-dimensional vector $X=$ [spending output taxes]. Subsequent studies have extended the system to include other key variables such as inflation, private consumption, the real exchange rate and the interest rate.

As stressed by Perotti (2007), the reduced form residuals capture three components: automatic stabilisers, discretionary fiscal policy responses (for instance systematically changing the tax rate in response to the business cycle) and random discretionary fiscal policy responses. The later is what the structural fiscal shock is meant to capture.

The structural VAR model takes the following form:

$$
A_{0} X_{t}=\sum_{i=1}^{k} A_{i} X_{t-i}+B v_{t}
$$

The matrix $A_{0}$ describes the contemporaneous relationships among the variables in the vector $X_{t}$. The matrix $B$ describes the relation between the reduced form residuals $e_{t}$ and the structural form residuals $v_{t}$ :

$$
v_{t}=B^{-1} A_{0} e_{t}
$$

The dynamics of the variables following a one unit increase in the current value of the structural residual in the fiscal equation holding all other residuals fixed (that is a "structural fiscal shock") can be summarised in the impulse responses of the variables included in the system.

The challenge is how to pin down the structural shocks. To compute the impulse responses of the variables in the system, the matrices $A_{0}, B$ and the variance-covariance matrix of the structural residuals $\left(\Sigma_{v}\right)$ must be estimated. However, the system can be identified only if some coefficients in the matrices $B^{-1} A_{0}$ are restricted to take certain values typically justified by theoretical considerations ("identifying assumptions"). Even with the assumption that the matrix $B$ is the identity matrix, this exclusion restriction is not enough to identify the system. The diagonal matrix $\Sigma_{v}$ can be used to express $\Sigma_{e}$ as follows: $A_{0}^{-1} \Sigma_{v}\left(A_{0}^{-1}\right)^{\prime}=\Sigma_{e}$. Still, this relation does not identify a unique solution.

\subsubsection{Identification}

Perotti (2007) provides a detailed scrutiny of strategies that have been used in the literature to identify a fiscal policy shock. This section presents a brief overview. There are four approaches to identify structural fiscal shocks.

The first approach is the recursive formulation (Cholesky decomposition). While this strategy was originally proposed by Sims (1980) not in the context of identifying structural fiscal shocks, subsequent works have applied this identification approach to fiscal policy analysis (for example Corsetti and Müller 2006 and Fatas and Mihov 2001). According to this approach, the first variable ordered in the system responds only to its own exogenous shock. In the 3-dimensional example above, spending is ordered first. This implies government spending does not contemporaneously react to shocks to the economy. The second variable, output, responds to the first variable (spending) and its own shock. The third variable, taxes, reacts to its own shock and shocks to the previous two variables, and so on. Technically, the matrix $A_{0}$ is a lower triangular matrix with ones on the main diagonal, and the matrix $B$ is the identity matrix:

$$
\left[\begin{array}{ccc}
1 & 0 & 0 \\
a_{21} & 1 & 0 \\
a_{31} & a_{32} & 1
\end{array}\right]\left[\begin{array}{l}
e^{\text {spending }} \\
e^{\text {output }} \\
e^{\text {taxes }}
\end{array}\right]=\left[\begin{array}{lll}
1 & 0 & 0 \\
0 & 1 & 0 \\
0 & 0 & 1
\end{array}\right]\left[\begin{array}{l}
v^{\text {spending }} \\
v^{\text {output }} \\
v^{\text {taxes }}
\end{array}\right]
$$


In this context, the ordering of the variables plays a crucial role because it defines the direction of the causal relationship. Strictly, there is no theoretical guide for ordering the variables, and the assumptions behind any ordering are nontrivial. For instance, positioning taxes after output excludes a priori contemporaneous effects on any components of output including private consumption, which is a rather strong assumption.

The second approach is the structural identification approach proposed by Blanchard and Perotti (2002), according to which some elements of the Matrix $B^{-1} A_{0}$ can be obtained by using information on elasticities of spending and taxes to output. These elasticities correspond to certain elements in the matrix $A_{0}$. Computing these elasticities is described in Perotti (2007) and Van den Noord (2000). For example, based on Perotti (2007), the value of the output elasticity of net taxes $\left(a_{32}\right)$ for the USA is computed to be 1.85 . This value is then exogenously imposed on the VAR model. In our example, the system then takes the following form:

$$
\left[\begin{array}{ccc}
1 & 0 & 0 \\
a_{21} & 1 & a_{23} \\
0 & 1.85 & 1
\end{array}\right]\left[\begin{array}{l}
e^{\text {spending }} \\
e^{\text {output }} \\
e^{\text {taxes }}
\end{array}\right]=\left[\begin{array}{ccc}
1 & 0 & 0 \\
0 & 1 & 0 \\
b_{31} & 0 & 1
\end{array}\right]\left[\begin{array}{l}
v^{\text {spending }} \\
v^{\text {output }} \\
v^{\text {taxes }}
\end{array}\right]
$$

The crucial assumption needed for this identification approach is that government spending does not react within a certain period, typically assumed to be a quarter, to shocks to the economy. This is based on the idea that fiscal actions are subject to the decision lag; i.e. the time needed for fiscal policy makers to respond to the status of the economy. Estimating $b_{31}$ while setting $b_{13}=0$ implies that spending decisions come before tax decisions. Perotti (2007) imposes further elasticities conditions (exogenous values) in a system that includes two additional variables: inflation and the interest rate. ${ }^{5}$

The third approach is the sign restriction approach developed by Uhlig (2005) and applied to fiscal policy analysis by Mountford and Uhlig (2009) and Pappa (2009a, and 2009b). Contrary to the previous two approaches, the sign restriction approach does not require imposing zero contemporaneous effects on some variables, but requires restrictions on the sign of the impulse responses of the fiscal variables. For example, Mountford and Uhlig (2009) identify a government spending shock as a shock that is orthogonal to monetary and business cycle shocks, and for which government revenue increases for four quarters after the shock. Hence, they impose also sign restrictions to identify monetary and business cycle shocks. Pappa (2009b), by referring to RBC and NK DSGE models, identifies a government spending shock as a shock that contemporaneously increases output and the budget deficit. The use of sign restrictions for fiscal policy analysis is not unproblematic. Given the various competing theoretical predictions, prior information upon the qualitative responses of the variables can be of a limited use in this context. In fact, we are interested in the signs of the effects per se. Also, another potential drawback of this method is that more than one model may satisfy the sign restrictions for the impulse response functions but at the same time have different quantitative effects. Fry and Pagan (2007) and Paustian (2007) provide a detailed discussion on the use of sign restrictions for identification. In general, the sign restriction approach does not necessarily yield better estimates of the effects of the structural shocks than other approaches such as the SVAR approach.

The fourth approach is the narrative (or dummy variables) approach, which is implemented in studies that are particularly interested in the U.S. economy. Ramey and Shapiro (1998) and Ramey (2008) construct a dummy capturing dates of exogenous increases in government defence spending. These are the episodes of Vietnam War, Korean War, the Carter-Reagan build-up, and 9/11. Romer and Romer (forthcoming) apply the idea for legislated tax changes. ${ }^{6}$ While several of those studies, for example Ramey and Shapiro (1998) and Romer and Romer (forthcoming), rely on single-equation techniques, others such as Favero, C. and Giavazzi, F. (2009) apply this identification approach in a

\footnotetext{
${ }^{5}$ One earlier seminal contribution advocating the use of SVAR is Blanchard and Quah (1989) who identify supply shocks as shocks that have permanent effects (long-run restrictions). However, economic theory suggests that fiscal policy has short-run effects. Therefore, the identification in the context of fiscal policy primarily relies on contemporaneous restrictions.

${ }^{6}$ A detailed description and timing can be found in Ramey (2008).
} 
VAR setup. The fiscal shock is identified by the impulse response of the dates-dummy. Specifically, the new reduced form VAR is:

$$
X_{t}=\sum_{i=1}^{k} M_{i} X_{t-i}+\sum_{j=0}^{l} D_{j} d_{t-j}+e_{t}
$$

where $j$ is the lag order associated with the dates-dummy $d$, and $D$ is the associated matrix of coefficients. The disadvantage of this approach is that other fiscal shocks of different implications might have occurred parallel to the identified episodes. Further, to some extent the dynamics of all variables is assumed to be the same in each episode.

\subsubsection{Cautious interpretation}

The previous subsection has highlighted the complexity of identifying structural fiscal shocks. While it is natural to ask which of the discussed identification scheme is best suited for fiscal policy analysis, it is a rather delicate matter to favour one method to another as all are subject to drawbacks.

In conjunction with the mentioned identification difficulties, fiscal actions can be anticipated due to the implementation lag, i.e. the period of time until the change in fiscal policy is indeed implemented. Theoretically, if consumers are Ricardian anticipation may yield different impulse responses. Perotti (2005) examines how the announced OECD forecasts of government spending and GDP growth affect the VAR results, and emphasises that "there is a little evidence that the VAR innovations are predictable, p. 13". Blanchard and Perotti (2002) and Tenhofen and Wolff (2007) account for anticipated shocks by allowing agents at time $t$ to fully anticipate the fiscal shock that will occur at time $t+1$. This is done by augmenting the output equation or consumption equation in the VAR system with expected values at time $t$ of fiscal variables at time $t+1 .^{7}$ Mertens and Ravn (2009) extend the analysis of the narrative approach of Romer and Romer (forthcoming) to account for anticipation effects. They distinguish between the announcement date (the time when the legislation is signed) and the implementation date (the date at which tax changes are enforced). According to Mertens and Ravn (2009), a tax change is anticipated if the time span between these two dates is longer than a certain period assumed to be 90 days.

Apart of difficulties in relation to identification and accounting for anticipation, other issues are under spot. Earlier VAR studies ignored the budget government constraint. Chung and Leeper (2007) and Favero and Giavazzi (2007) point out that omitting the debt dynamics yields biased results. The argument of Chung and Leeper (2007) is based upon accounting for fiscal financing. The idea is that following the fiscal shock the present value balance has to be achieved, and hence must be imposed on the VAR model by introducing the intertemporal government budget constraint. While Chung and Leeper (2007) introduce a linearised version of the government budget constraint into an otherwise standard VAR, Favero and Giavazzi (2007) argue in favour of accounting for non-linearity. For example, a 5-dimnsional VAR model (that adds inflation and the interest rate to the previous 3dimisional VAR example) represents all variables that determine the time path of the level of debt. However, the VAR is linear whereas the government budget constraint is a non-linear relation. Consequently, the accuracy of the linear approximation of the debt equation (the stationarity of debt) resolves whether or not the non-linear debt equation has to be included. Favero and Giavazzi (2009) find that in principle there are no differences between the impulse responses of U.S variables to a tax shock with and without the inclusion of a non-linear government budget constraint. ${ }^{8}$ Some recent studies such as Dungey and Fry (2009) and Bilbiie, Meier and Müller (2008) take the debt dynamics into consideration by including a debt equation in the VAR.

Another important issue is with regard to the frequency of the data. For many economies, there are no quarterly fiscal variables. Quarterly data are either not revised or interpolated. Additionally, anticipation effects become less pronounced with annual data. From this standpoint the use of the annual data is an advantage. However, the assumption that government spending does not contemporaneously react to the state of the economy becomes stronger with annual data. Furthermore,

\footnotetext{
${ }^{7}$ Expectation augmented VAR gives rise to a correlation between the residuals and some explanatory variables. Therefore, instead of estimating every equation by OLS, some equations have to be estimated by instrumental variables; Blanchard and Perotti (2002) and Tenhofen and Wolff (2007).

${ }^{8}$ Favero and Giavazzi (2009) find some differences however for the sub-sample starting from 1981 to 2006.
} 
the use of annual data restricts the analysis due to shorter time series. For example, Beetsma Giuliodori and Klaassen (2008) employ a panel of European countries to circumvent this issue of degrees of freedom. However, while panel estimates can be useful to assess qualitative responses, they are not informative about country-specific quantitative responses of variables of interest.

\subsection{Overview of empirical results}

This section provides a summary of recent empirical evidence on the effects of fiscal policy shocks on macroeconomic aggregates. It is important to note that the results reviewed below are not directly comparable. The studies differ not only with respect to the identification strategies but are also based on the inclusion of different variables, stochastic and deterministic components, different sample periods, different numbers of chosen lags and other details. Also, studies differ in the exact employed government expenditure and tax series. Government spending is the sum of government consumption and government investment. In addition, government spending is categorised according to government functions such as defence spending, pension etc. The series of government revenue from taxation has also to be constructed from various components. ${ }^{9}$

Since most studies report several magnitudes of the same effect scaled with different units, this summary focuses on the qualitative effects obtained from benchmark results. An exception is the multiplier on output, which is reported according to benchmark estimates on impact; if applicable.

\subsubsection{The response of output, consumption, labour market and the interest rate}

Table (2) summarises recent VAR findings on the impacts of a positive government spending shock while table (3) summarises recent VAR findings on the impacts of a tax shock on key macroeconomic aggregates. Details on the construction of fiscal variables, on cumulative, peak responses and the exact shapes of the impulse response functions of the key variables can be found in the corresponding studies. The results are as follows:

Output response: Regardless of the chosen identification approach, several VAR studies report an increase in output in a hump-shaped manner as a result of a positive government spending shock; for example Blanchard and Perotti (2002), De Castro and De Cos (2008), Fatas and Mihov (2001) and Pappa (2009b). However, the size of the impact and the peak response vary across studies. In fact, even within many studies the size of the multiplier is dependent on the employed specification or the sample period. Notably, the multiplier is negative for some sub-samples for Australia, Canada and the UK; Perotti (2005). For the U.S. economy Perotti (2005) stresses that the effects of fiscal shocks on GDP and its components have declined in the last twenty years. Bilbiie, Meier and Müller (2008) explain this by the role of increased participation in the asset market and more active monetary policy. Blanchard and Perotti (2002) find no evidence on changes in the response of output due to an anticipation of the shock. The multiplier even gets larger. Concerning a tax shock, Blanchard Perotti (2002) find that a tax increase has a negative impact multiplier of about 0.7 in the US. Results based on the sign restriction or narrative approach confirm this negative multiplier; Caldara and Kamps (2008), Mountford and Uhlig (2009) and Romer and Romer (forthcoming). However, as in the case of a spending shock, the sign of the multiplier changes depending on the sample period for some OECD economies; Perotti (2005). Accounting for anticipation by Mertens and Ravn (2009) yields a negative multiplier for an anticipated tax cut in the period before implementation. Afterwards, output increases. The results summarised in tables (2) and (3) do not provide unambiguous evidence that the multiplier of a tax cut is smaller than that of an increase in government spending as the Keynesian theory predicts. Arin and Koray (2006) distinguish between different series of tax revenues. They find that positive income tax shocks have a negative effect on output whereas positive corporate income tax shocks have a surprisingly positive effect on output in Canada. This indicates that using an aggregate series of tax revenues might be misleading since changes in different tax categories may have different implications on the economy.

\footnotetext{
${ }^{9}$ Our focus is on recent estimates (especially VAR studies) of the multipliers and short-run effects of fiscal shokcs on key variables. A popular strand of the literature in the 90s attempts to estimate potential effects of fiscal policy on long-run economic growth rates; see for instance Kneller, Bleaney and Gemmell (1998).
} 
Consumption response: The results are not clear-cut. Studies using the recursive or BlanchardPerotti identification approach find that a positive government spending shock has a positive effect on consumption; for instance Fatas and Mihov (2001) and Blanchard and Perotti (2002). Using the sign restriction approach, Pappa (2009b) reports also a positive effect on consumption in contrast to Mountford and Uhlig (2009) who find that the response of consumption is zero and insignificant. The narrative approach of Ramey (2008) yields a negative effect on consumption. Thus far, the narrative approach of identification is exclusively applied to the U.S. economy. After accounting for anticipation of the fiscal shock, consumption also declines in the study by Tenhofen and Wollf (2007). Thus, VAR estimates do not provide full support in favour of one theoretical prediction on consumption against another. This is true also in the case of a tax shock. Nevertheless, overall consumption seems to increase as a result of a tax cut in several studies such as Blanchard and Perotti (2002) and Romer and Romer (forthcoming). A non-positive response of consumption is found in for example in studies such as Ramey and Shapiro (1998), Ramey (2008) and Tenhofen and Wolff (2007) which can be interpreted as studies capturing anticipation effects. Linking the reported results in tables (2) and (3) to the theory, overall, the recursive and Blanchard and Perotti approaches support the Keynesian and modified DSGE models (for example the deep habits and the spending reversals model) in which consumption respond positively to a fiscal expansion. The results of studies that employ the narrative approach seem to be in line with the standard forward Ricardian behaviour.

Labour market response: Concerning the reaction of employment, Burnside, Eichenbaum and Fisher (2004), Pappa (2009a) and Ramey (2007) document an increase in employment following a positive spending shock. This is in line with the reaction of output and the various theories summarised in table (1) since no model predicts a decrease in employment following a positive fiscal shock. Few studies consider the reaction of the real wage (results are not reported in tables (2) or (3)). The results are mixed. Pappa (2009a) and Blanchard and Perotti (2002) report an increase while Burnside, Eichenbaum and Fisher (2004) report a decrease in the real wage in response to a positive spending shock.

Interest rate response: The interest rate increases following a fiscal expansion according to several empirical studies such as Ramey (2008) in line with predictions of DSGE models and a closed economy Keynesian model. In Caldara and Kamps (2008), the interest rate does not react. The finding of some VAR studies of a negative impact of a fiscal expansion on the interest rate is rather difficult to interpret theoretically.

In connection to the estimates reviewed in tables (2) and (3), Laubach (2009) using a one-equation econometric methodology, estimates that a one percentage point increase in projected deficit-to-GDP ratio in the US, ceteris paribus, increases long-term interest rates by 20 to 30 basis points. In the European Monetary Union, Faini (2006) reports that a fall in the primary surplus of a member country raises its interest rate by about 3 basis points.

Table (2) The effects of a government spending shock*

\begin{tabular}{|c|c|c|c|c|c|c|c|c|}
\hline Study & Country & Sample & $\begin{array}{c}\text { Identification } \\
\text { strategy }\end{array}$ & Output & Consumption & Employment & $\begin{array}{c}\text { Interest } \\
\text { rate }\end{array}$ & Comments \\
\hline $\begin{array}{c}\text { Beetsma et al. } \\
(2008)\end{array}$ & $\begin{array}{l}\text { Panel } \\
\text { EU14 }\end{array}$ & $\begin{array}{c}\text { annual } \\
1970-2004\end{array}$ & recursive & 1.2 & & & & \\
\hline \multirow{2}{*}{$\begin{array}{l}\text { Bilbiie et al. } \\
\quad(2008)\end{array}$} & USA & $\begin{array}{c}\text { quarterly } \\
1983-2004 \\
\end{array}$ & recursive & 0.94 & + & & & \multirow{2}{*}{$\begin{array}{l}\text { the reported } \\
\text { multiplier is a } 4 \\
\text { quarters } \\
\text { cumulative } \\
\text { response }\end{array}$} \\
\hline & USA & $\begin{array}{c}\text { quarterly } \\
1957-1979\end{array}$ & recursive & 1.71 & + & & & \\
\hline \multirow{2}{*}{$\begin{array}{l}\text { Blanchard and } \\
\text { Perotti (2002) }\end{array}$} & USA & $\begin{array}{c}\text { quarterly } \\
1960-1997\end{array}$ & $\begin{array}{c}\text { Blanchard } \\
\text { and Perotti }\end{array}$ & 0.84 & + & & & \\
\hline & USA & $\begin{array}{c}\text { quarterly } \\
1960-1997 \\
\end{array}$ & $\begin{array}{l}\text { expectation } \\
\text { augmented } \\
\end{array}$ & ca 2 & & & & \\
\hline $\begin{array}{l}\text { Burnside et al. } \\
\text { (2004) }\end{array}$ & USA & $\begin{array}{c}\text { quarterly } \\
1947-1995\end{array}$ & narrative & + & $=$ & + & & \\
\hline \multirow{3}{*}{$\begin{array}{c}\text { Caldara and } \\
\text { Kamps (2008) }\end{array}$} & USA & $\begin{array}{c}\text { quarterly } \\
1955-2006\end{array}$ & recursive & 1 & + & $=$ & $=$ & \\
\hline & USA & $\begin{array}{c}\text { quarterly } \\
1955-2006\end{array}$ & $\begin{array}{c}\text { Blanchard } \\
\text { and Perotti }\end{array}$ & 1 & + & $=$ & $=$ & \\
\hline & USA & $\begin{array}{c}\text { quarterly } \\
1955-2006 \\
\end{array}$ & $\begin{array}{c}\text { sign } \\
\text { restrictions }\end{array}$ & ca 0.5 & $=$ & $=$ & $=$ & \\
\hline
\end{tabular}




\begin{tabular}{|c|c|c|c|c|c|c|c|c|}
\hline & USA & $\begin{array}{c}\text { quarterly } \\
1955-2006\end{array}$ & narrative & 0 & + & $=$ & $=$ & \\
\hline $\begin{array}{l}\text { De Castro } \\
\text { and De Cos } \\
(2008)\end{array}$ & Spain & quarterly & $\begin{array}{l}\text { Blanchard } \\
\text { and Perotti }\end{array}$ & 1.31 & + & & + & $\begin{array}{l}\text { the reported } \\
\text { multiplier is a } 4 \\
\text { quarters } \\
\text { cumulative } \\
\text { response }\end{array}$ \\
\hline $\begin{array}{l}\text { Dungey and } \\
\text { Fry (2009) }\end{array}$ & $\begin{array}{l}\text { New } \\
\text { Zealand }\end{array}$ & $\begin{array}{c}\text { quarterly } \\
1983-2006\end{array}$ & $\begin{array}{c}\text { sign } \\
\text { restrictions }\end{array}$ & + & - & & + & $\begin{array}{l}\text { the identification } \\
\text { method } \\
\text { combines SVAR } \\
\text { restrictions on } \\
\text { non-fiscal } \\
\text { variables and } \\
\text { sing restrictions } \\
\text { on fiscal shocks }\end{array}$ \\
\hline $\begin{array}{c}\text { Fatas and } \\
\text { Mihov (2001) }\end{array}$ & USA & $\begin{array}{c}\text { quarterly } \\
1960-1996 \\
\end{array}$ & recursive & 0.3 & + & + & + & $\begin{array}{l}\text { peak multiplier } \\
\text { in } 2 \text { years }\end{array}$ \\
\hline \multirow[b]{2}{*}{$\begin{array}{l}\text { Favero and } \\
\text { Giavazzi } \\
(2007)\end{array}$} & USA & $\begin{array}{c}\text { quarterly } \\
1980-2006\end{array}$ & $\begin{array}{c}\text { Blanchard } \\
\text { and Perotti }\end{array}$ & 0.127 & & & - & \multirow{2}{*}{$\begin{array}{l}\text { the reported } \\
\text { multiplier is a } 4 \\
\text { quarters } \\
\text { cumulative } \\
\text { response; after } \\
\text { accounting for } \\
\text { debt dynamics }\end{array}$} \\
\hline & USA & $\begin{array}{c}\text { quarterly } \\
1960-1979\end{array}$ & $\begin{array}{l}\text { Blanchard } \\
\text { and Perotti }\end{array}$ & 0.056 & & & - & \\
\hline $\begin{array}{l}\text { Galí et al. } \\
\text { (2007) }\end{array}$ & USA & $\begin{array}{c}\text { quarterly } \\
1954-2003\end{array}$ & $\begin{array}{c}\text { Blanchard } \\
\text { and Perotti }\end{array}$ & 0.78 & + & + & & \\
\hline $\begin{array}{l}\text { Giordano et } \\
\text { al. (2007) }\end{array}$ & Italy & $\begin{array}{c}\text { quarterly } \\
1982-2004\end{array}$ & $\begin{array}{l}\text { Blanchard } \\
\text { and Perotti }\end{array}$ & 0.2 & + & + & - & $\begin{array}{l}\text { interest rate } \\
\text { increases after } \\
\text { about one year }\end{array}$ \\
\hline $\begin{array}{l}\text { Heppke-Falk } \\
\text { et al. (2006) }\end{array}$ & Germany & $\begin{array}{c}\text { quarterly } \\
1974-2004\end{array}$ & $\begin{array}{l}\text { Blanchard } \\
\text { and Perotti }\end{array}$ & 0.62 & + & & + & \\
\hline $\begin{array}{c}\text { Mountford } \\
\text { and Uhlig } \\
(2009)\end{array}$ & USA & $\begin{array}{c}\text { Quarterly } \\
1955-2000\end{array}$ & $\begin{array}{c}\text { sign } \\
\text { restrictions }\end{array}$ & 0.44 & $=$ & & $=$ & \\
\hline Pappa (2009a) & USA & $\begin{array}{c}\text { annual } \\
1969-2001\end{array}$ & $\begin{array}{c}\text { sign } \\
\text { restrictions }\end{array}$ & & & + & & \\
\hline \multirow{5}{*}{$\begin{array}{l}\text { Pappa } \\
\text { (2009b) }\end{array}$} & Canada & $\begin{array}{c}\text { quarterly } \\
1970-2007\end{array}$ & $\begin{array}{c}\text { sign } \\
\text { restrictions }\end{array}$ & 0.18 & + & + & & \multirow{5}{*}{$\begin{array}{l}\text { results reported } \\
\text { for a government } \\
\text { consumption } \\
\text { shock. Pappa } \\
\text { (2009b) reports } \\
\text { results for } \\
\text { government } \\
\text { investment and } \\
\text { employment } \\
\text { shocks }\end{array}$} \\
\hline & $\begin{array}{c}\mathrm{EU} \\
\text { aggregate }\end{array}$ & $\begin{array}{c}\text { quarterly } \\
1991-2007 \\
\end{array}$ & $\begin{array}{c}\text { sign } \\
\text { restrictions }\end{array}$ & 0.16 & + & + & & \\
\hline & Japan & $\begin{array}{c}\text { quarterly } \\
1970-2007\end{array}$ & $\begin{array}{c}\text { sign } \\
\text { restrictions }\end{array}$ & 0.13 & + & + & & \\
\hline & UK & $\begin{array}{c}\text { quarterly } \\
1970-2007\end{array}$ & $\begin{array}{c}\text { sign } \\
\text { restrictions }\end{array}$ & 0.13 & + & + & & \\
\hline & USA & $\begin{array}{c}\text { quarterly } \\
1970-2007 \\
\end{array}$ & $\begin{array}{c}\text { sign } \\
\text { restrictions }\end{array}$ & 0.74 & + & + & & \\
\hline \multirow{10}{*}{ Perotti (2005) } & Australia & $\begin{array}{c}\text { quarterly } \\
1980-2001\end{array}$ & $\begin{array}{c}\text { Blanchard } \\
\text { and Perotti }\end{array}$ & .21 & + & & + & \multirow{10}{*}{$\begin{array}{l}\text { the reported } \\
\text { multiplier is a } 4 \\
\text { quarters } \\
\text { cumulative } \\
\text { response }\end{array}$} \\
\hline & Australia & $\begin{array}{c}\text { quarterly } \\
1960-1979 \\
\end{array}$ & $\begin{array}{l}\text { Blanchard } \\
\text { and Perotti }\end{array}$ & -0.1 & + & & - & \\
\hline & Canada & $\begin{array}{c}\text { quarterly } \\
1980-2001\end{array}$ & $\begin{array}{l}\text { Blanchard } \\
\text { and Perotti }\end{array}$ & -.28 & - & & + & \\
\hline & Canada & $\begin{array}{c}\text { quarterly } \\
1960-1979 \\
\end{array}$ & $\begin{array}{r}\text { Blanchard } \\
\text { and Perotti }\end{array}$ & 0.59 & + & & + & \\
\hline & Germany & $\begin{array}{c}\text { quarterly } \\
1975-1989 \\
\end{array}$ & $\begin{array}{c}\text { Blanchard } \\
\text { and Perotti }\end{array}$ & .4 & - & & - & \\
\hline & Germany & $\begin{array}{c}\text { quarterly } \\
1960-1974\end{array}$ & $\begin{array}{c}\text { Blanchard } \\
\text { and Perotti }\end{array}$ & 0.41 & - & & + & \\
\hline & UK & $\begin{array}{c}\text { quarterly } \\
1980-2001 \\
\end{array}$ & $\begin{array}{l}\text { Blanchard } \\
\text { and Perotti }\end{array}$ & -.2 & - & & + & \\
\hline & UK & $\begin{array}{c}\text { quarterly } \\
1960-1979\end{array}$ & $\begin{array}{l}\text { Blanchard } \\
\text { and Perotti }\end{array}$ & 0.48 & + & & + & \\
\hline & USA & $\begin{array}{c}\text { quarterly } \\
1980-2001\end{array}$ & $\begin{array}{c}\text { Blanchard } \\
\text { and Perotti }\end{array}$ & .31 & + & & + & \\
\hline & USA & $\begin{array}{c}\text { quarterly } \\
1960-1979 \\
\end{array}$ & $\begin{array}{c}\text { Blanchard } \\
\text { and Perotti }\end{array}$ & 1.13 & + & & - & \\
\hline
\end{tabular}




\begin{tabular}{|c|c|c|c|c|c|c|c|c|}
\hline \multirow{3}{*}{ Perotti (2007) } & Canada & $\begin{array}{c}\text { quarterly } \\
1947-2005\end{array}$ & $\begin{array}{l}\text { Blanchard } \\
\text { and Perotti }\end{array}$ & & & - & & \\
\hline & UK & $\begin{array}{c}\text { quarterly } \\
1947-2005\end{array}$ & $\begin{array}{l}\text { Blanchard } \\
\text { and Perotti }\end{array}$ & & & - & & \\
\hline & USA & $\begin{array}{c}\text { quarterly } \\
1947-2005\end{array}$ & $\begin{array}{l}\text { Blanchard } \\
\text { and Perotti }\end{array}$ & & & + & & \\
\hline Ramey (2008) & USA & $\begin{array}{c}\text { quarterly } \\
1947-2003\end{array}$ & narrative & ca 1 & - & + & + & \\
\hline $\begin{array}{c}\text { Ramey and } \\
\text { Shapiro } \\
(1998)\end{array}$ & USA & $\begin{array}{c}\text { quarterly } \\
1947-1996\end{array}$ & narrative & ca 1 & - & $=$ & - & $\begin{array}{l}\text { interest rate falls } \\
\text { on impact but } \\
\text { increases later }\end{array}$ \\
\hline $\begin{array}{l}\text { Ravn et al. } \\
\text { (2007) }\end{array}$ & $\begin{array}{l}\text { A panel } \\
\text { of } \\
\text { Australia, } \\
\text { Canada, } \\
\text { UK and } \\
\text { the USA }\end{array}$ & $\begin{array}{c}\text { quarterly } \\
\text { 1975-2005 }\end{array}$ & $\begin{array}{l}\text { Blanchard } \\
\text { and Perotti }\end{array}$ & 0.52 & + & & & \\
\hline $\begin{array}{l}\text { Tenhofen and } \\
\text { Wolff (2007) }\end{array}$ & USA & $\begin{array}{c}\text { quarterly } \\
1947-2006\end{array}$ & $\begin{array}{l}\text { expectation } \\
\text { augmented }\end{array}$ & & - & & & \\
\hline
\end{tabular}

* If the study does not consider a certain variable, the corresponding field in the table is kept empty. Further, if not otherwise stated, the reported magnitude of the multiplier is on impact. The cumulative peak response is usually larger than the impact effect. Details on cumulative and peak responses of output and other key variables can be found in the corresponding study. The sign "+" indicates a positive effect whereas the sign "-" indicates a negative effect. The sign "=" indicates no effect.

Table (3) The effects of a tax shock*

\begin{tabular}{|c|c|c|c|c|c|c|c|c|c|}
\hline Study & Country & Data & $\begin{array}{c}\text { Increase } \\
\text { or } \\
\text { decrease }\end{array}$ & $\begin{array}{c}\text { Identification } \\
\text { strategy }\end{array}$ & Output & Consumption & Employment & $\begin{array}{l}\text { Interest } \\
\text { rate }\end{array}$ & Comments \\
\hline $\begin{array}{c}\text { Arin and } \\
\text { Koray (2006) }\end{array}$ & Canada & $\begin{array}{c}\text { quarterly } \\
1960- \\
1999 \\
\end{array}$ & increase & recursive & - & & & - & $\begin{array}{l}\text { Shock to } \\
\text { income tax } \\
\text { revenues }\end{array}$ \\
\hline \multirow{2}{*}{$\begin{array}{l}\text { Blanchard and } \\
\text { Perotti (2002) }\end{array}$} & USA & $\begin{array}{c}\text { quarterly } \\
1960- \\
1997\end{array}$ & increase & $\begin{array}{l}\text { Blanchard } \\
\text { and Perotti }\end{array}$ & -0.69 & - & & & \\
\hline & USA & $\begin{array}{c}\text { quarterly } \\
1960- \\
1997 \\
\end{array}$ & increase & $\begin{array}{l}\text { expectation } \\
\text { augmented }\end{array}$ & ca 0 & & & & \\
\hline \multirow{3}{*}{$\begin{array}{c}\text { Caldara and } \\
\text { Kamps (2008) }\end{array}$} & USA & $\begin{array}{c}\text { quarterly } \\
1955- \\
2006 \\
\end{array}$ & increase & recursive & 0 & $=$ & $=$ & $=$ & \\
\hline & USA & $\begin{array}{c}\text { quarterly } \\
1955- \\
2006 \\
\end{array}$ & increase & $\begin{array}{l}\text { Blanchard } \\
\text { and Perotti }\end{array}$ & 0 & $=$ & $=$ & $=$ & \\
\hline & USA & $\begin{array}{c}\text { quarterly } \\
1955- \\
2006\end{array}$ & increase & $\begin{array}{l}\text { sign } \\
\text { restrictions }\end{array}$ & -0.8 & - & $=$ & $=$ & \\
\hline $\begin{array}{c}\text { De Castro } \\
\text { and De Cos } \\
(2008)\end{array}$ & Spain & $\begin{array}{c}\text { quarterly } \\
1980- \\
2004 \\
\end{array}$ & increase & $\begin{array}{l}\text { Blanchard } \\
\text { and Perotti }\end{array}$ & - & + & & + & \\
\hline $\begin{array}{l}\text { Dungey and } \\
\text { Fry (2009) }\end{array}$ & $\begin{array}{c}\text { New } \\
\text { Zealand }\end{array}$ & $\begin{array}{c}\text { quarterly } \\
1983- \\
2006\end{array}$ & increase & $\begin{array}{l}\text { sign } \\
\text { restrictions }\end{array}$ & + & - & & + & $\begin{array}{l}\text { the } \\
\text { identification } \\
\text { method } \\
\text { combines } \\
\text { SVAR } \\
\text { restrictions on } \\
\text { non-fiscal } \\
\text { variables and } \\
\text { sing } \\
\text { restrictions on } \\
\text { fiscal shocks }\end{array}$ \\
\hline \multirow{2}{*}{$\begin{array}{c}\text { Favero and } \\
\text { Giavazzi } \\
(2007)\end{array}$} & USA & $\begin{array}{c}\text { quarterly } \\
1980- \\
2006 \\
\end{array}$ & increase & $\begin{array}{l}\text { Blanchard } \\
\text { and Perotti }\end{array}$ & 0.016 & & & + & \multirow{2}{*}{$\begin{array}{l}\text { the reported } \\
\text { multiplier is a } \\
4 \text { quarters } \\
\text { cumulative } \\
\text { response; after } \\
\text { accounting for } \\
\text { debt dynamics }\end{array}$} \\
\hline & USA & $\begin{array}{c}\text { quarterly } \\
1960- \\
1979\end{array}$ & increase & $\begin{array}{l}\text { Blanchard } \\
\text { and Perotti }\end{array}$ & -0.249 & & & - & \\
\hline
\end{tabular}




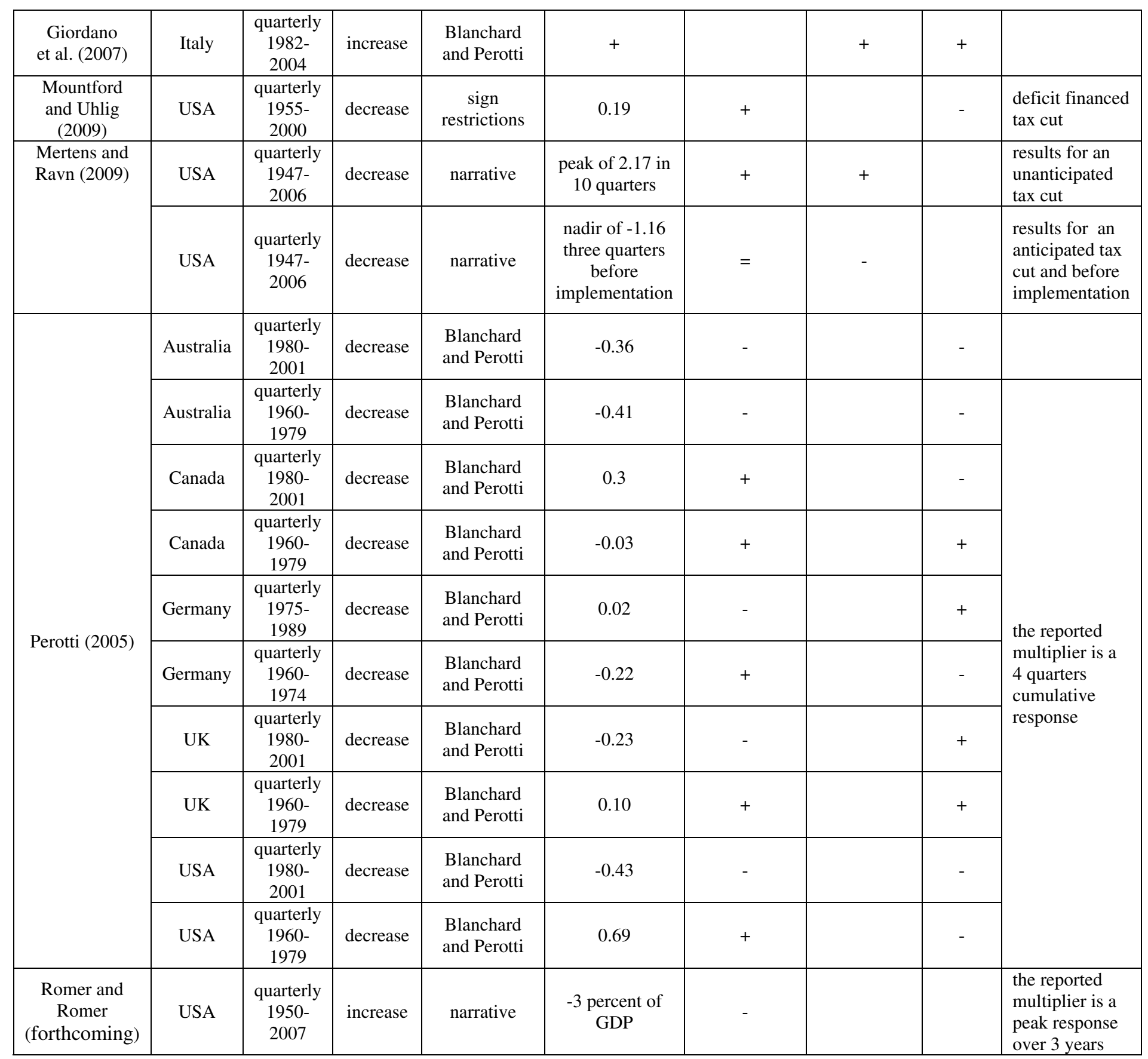

* If the study does not consider a certain variable, the corresponding field in the table is kept empty. Further, if not otherwise stated, the reported magnitude of the multiplier is on impact. The cumulative peak response is usually larger than the impact effect. Details on cumulative and peak responses of output and other key variables can be found in the corresponding study. The sign " + " indicates a positive effect whereas the sign "-" indicates a negative effect. The sign "=" indicates no effect. 
Table (4) The impact of a fiscal shock on the real exchange rate and the current account*

\begin{tabular}{|c|c|c|c|c|c|c|c|}
\hline Study & Country & A shock to & Identification & $\begin{array}{c}\text { Real } \\
\text { exchange } \\
\text { rate }\end{array}$ & $\begin{array}{c}\text { Terms of trade } \\
\text { (relative price } \\
\text { of imports) }\end{array}$ & $\begin{array}{l}\text { Relative } \\
\text { price } \\
\text { of non- } \\
\text { traded } \\
\text { goods }\end{array}$ & $\begin{array}{c}\text { Net exports } \\
\text { or current } \\
\text { account }\end{array}$ \\
\hline $\begin{array}{l}\text { Beetsma et } \\
\text { al. (2008) }\end{array}$ & $\begin{array}{l}\text { Panel } \\
\text { EU14 }\end{array}$ & $\begin{array}{c}\text { government } \\
\text { spending }\end{array}$ & recursive & + & & & - \\
\hline $\begin{array}{c}\text { Blanchard } \\
\text { and Perotti } \\
(2002)\end{array}$ & USA & $\begin{array}{l}\text { government } \\
\text { spending }\end{array}$ & $\begin{array}{l}\text { Blanchard } \\
\text { and Perotti }\end{array}$ & & & & - \\
\hline \multirow{4}{*}{$\begin{array}{l}\text { Corsetti and } \\
\text { Müller } \\
(2006)\end{array}$} & Australia & $\begin{array}{l}\text { budget } \\
\text { balance }\end{array}$ & recursive & & + & & + \\
\hline & Canada & $\begin{array}{l}\text { budget } \\
\text { balance }\end{array}$ & recursive & & - & & - \\
\hline & UK & $\begin{array}{l}\text { budget } \\
\text { balance }\end{array}$ & recursive & & - & & - \\
\hline & USA & $\begin{array}{l}\text { budget } \\
\text { balance }\end{array}$ & recursive & & - & & + \\
\hline $\begin{array}{l}\text { Kim and } \\
\text { Roubini } \\
\text { (2008) }\end{array}$ & USA & $\begin{array}{l}\text { budget } \\
\text { balance }\end{array}$ & recursive & - & & & + \\
\hline \multirow{4}{*}{$\begin{array}{c}\text { Monacelli } \\
\text { and Perotti } \\
\text { (forthcoming) }\end{array}$} & Australia & $\begin{array}{c}\text { government } \\
\text { spending }\end{array}$ & $\begin{array}{l}\text { Blanchard } \\
\text { and Perotti }\end{array}$ & - & & - & - \\
\hline & Canada & $\begin{array}{c}\text { government } \\
\text { spending }\end{array}$ & $\begin{array}{c}\text { Blanchard } \\
\text { and Perotti }\end{array}$ & - & & - & $=$ \\
\hline & UK & $\begin{array}{c}\text { government } \\
\text { spending }\end{array}$ & $\begin{array}{c}\text { Blanchard } \\
\text { and Perotti }\end{array}$ & - & & - & - \\
\hline & USA & $\begin{array}{l}\text { government } \\
\text { spending }\end{array}$ & $\begin{array}{l}\text { Blanchard } \\
\text { and Perotti }\end{array}$ & - & $\begin{array}{c}+ \text { (impact) } \\
- \text { (cumulative) }\end{array}$ & - & - \\
\hline $\begin{array}{c}\text { Monacelli } \\
\text { and Perotti } \\
(2008)\end{array}$ & USA & $\begin{array}{l}\text { government } \\
\text { spending }\end{array}$ & $\begin{array}{l}\text { Blanchard } \\
\text { and Perotti }\end{array}$ & & + & - & \\
\hline $\begin{array}{l}\text { Müller } \\
(2008)\end{array}$ & USA & $\begin{array}{l}\text { government } \\
\text { spending }\end{array}$ & recursive & & + & & + \\
\hline $\begin{array}{l}\text { Ravn et al. } \\
\text { (2007) }\end{array}$ & $\begin{array}{l}\text { A panel of } \\
\text { Australia, } \\
\text { Canada, } \\
\text { UK and } \\
\text { the US. }\end{array}$ & $\begin{array}{l}\text { government } \\
\text { spending }\end{array}$ & recursive & - & & & - \\
\hline
\end{tabular}

* If the study does not consider a certain variable, the corresponding field in the table is kept empty. Further, if not otherwise stated, the reported magnitude of the multiplier is on impact. The cumulative response may differ from the impact effect. Details on cumulative and peak responses can be found in the corresponding study. The sign "+" indicates a positive effect whereas the sign "-" indicates a negative effect. The sign "=" indicates no effect.

\subsubsection{The response of external sector variables}

Table (4) summarises the results of studies with a focal interest on the dynamics of external sector variables resulting from a fiscal policy shock.

The response of the real exchange rate and other relative prices: In most empirical studies, an expansionary fiscal shock causes depreciation of the real exchange rate; for example Monacelli and Perotti (forthcoming). This finding cannot be reconciled with Keynesian and standard DSGE predications. It is consistent however with modified DSGE models (for example the model with deep habits). The terms-of-trade (i.e. the relative price of imports) appreciate in Monacelli and Perotti (forthcoming) but depreciate in Müller (2008). The relative price of non-traded goods depreciates following a fiscal expansion; Monacelli and Perotti (forthcoming).

The response of net exports and the current account (twin deficit hypothesis): Beetsma, Giuliodori and Klaassen (2008) using a European panel and Monacelli and Perotti (forthcoming) employing US data provide support in favour of the twin deficit hypothesis. On the contrary, the results of Kim and Roubini (2008) do not support this view for the U.S. economy. Corsetti and Müller (2006) distinguish between small open economies, such as Canada, for which there is evidence of the twin deficit hypothesis, and relatively closed economies, the US, for which there is no support for the twin deficit 
hypothesis. In this context, there is a large older literature that examines the response of the trade balance and the current account to fiscal policy via estimating a single equation rather than a system of VAR. Lane and Perotti (1998) examine whether fiscal policy effects on the trade balance in OECD countries vary depending on the exchange rate regimes. They conclude that a fiscal expansion worsens the trade balance especially under a flexible exchange rate regime.

\subsubsection{Empirical evidence on fiscal policy externalities}

As discussed in the theoretical overview, cross-border effects of domestic fiscal changes can occur through affecting international trade, the interest rate and the exchange rate. Fiscal policy externality in the Euro Area has been the subject of several empirical studies. Faini (2006) investigates fiscal policy spill-over in the European Monetary Union through the interest rate channel by using single equation panel techniques. According to his finding, a 1 percent decrease in the primary surplus of a member country increases the interest rate of a typical member by 41 basis points. Overall, the evidence supports the interest rate channel of fiscal externalities; a fiscal expansion in one member country increases the union-wide interest rate.

Beetsma, Giuliodori and Klaassen (2006) address the trade channel of externalities in two steps. First, they estimate the effect of a fiscal expansion by means of a (European) panel VAR. Second, they impose homogeneity restrictions concerning the reaction of output and plug these estimates in a trade-gravity type of equation. The results suggest, for example, that an increase in German public spending of one percent of GDP raises the exports of the rest of the European countries in the sample by 2.2 percent boosting their income by about 0.15 percent.

In contrast to the previous two studies, Hebous and Zimmermann (2010) employ an integrated approach, the Global Vector Autoregression (GVAR), to estimate spillover effects of a budget deficit shock in one member in the Euro Area into the rest of the currency union. This approach derives a large multi-country system treating all variable as endogenous. ${ }^{10}$ Hebous and Zimmermann (2010) find that the expansionary domestic effects of a budget deficit shock on output in one member country are much smaller compared to the effects resulting from an area-wide shock (a weighted average of the shocks across the Euro Area countries). This may indicate to the importance of coordinated fiscal actions at the level of the Euro Area.

While the above mentioned works focus on fiscal policy externalities in the EU, Arin and Koray (2009) consider the transmission of fiscal shocks from the US to Canada. They find a negative effect of U.S. government spending shocks on Canadian output while U.S. tax shocks have no significant effects on Canadian output.

\subsubsection{A comment on macroeconometric models}

International and national policy institutions rely on large scale macroeconometric (structural) models to give a quantitative assessment of a simulated policy change. Typically, these models are, to various degrees, a hybrid of theory and practice. Some popular models largely extend the standard DSGE models in order to fit the data.

Perotti (2005) indicates that VAR point estimates of the multiplier are in general smaller or equal to those obtained from macroeconometric models for the US economy. However, Cogan, Cwik, Taylor and Wieland (forthcoming) provide a sceptical quantitative assessment of the size of the multiplier typically cited for the US economy by comparing the predictions of different macroeconomic models including the model of Smets and Wouters (2003). Further computational experiments can be found in Uhlig (2009) who complements the work of Cogan, Cwik, Taylor and Wieland (forthcoming) by focusing on the role of distortionary taxes. Uhlig (2009) concludes that the initial positive effect of the government spending multiplier comes at the cost of reducing output in subsequent periods. Further, this cost of potentially declining output is lower in the case of a tax cut than an increase government spending.

Erceg, Guerrieri and Gust (2005) calibrate one of the Fed's models to the U.S. economy to examine the effects of an expansionary fiscal shock on the U.S. trade balance. According to their

\footnotetext{
${ }^{10}$ The GVAR is a multi-country VAR model developed by Pesaran, Schuermann and Weiner (2004) to examine the effects of global risks on a bank's loan portfolio.
} 
findings, a 1 percent increase in the ratio of government spending to GDP induces a 0.2 percentage points decreases in the trade balance ratio. Cwik and Wieland (2009) find no support for positive spillover effects of fiscal expansion within the Euro Area. An overview of earlier results of some popular macroeconometric models can be found in Hemming, Kell and Mahfouz (2002) and in Henry, de Cos and Momigliano (2008) for Europe.

Finally, official agencies forecast expenditures and revenue associated with a proposed policy change. Forecasts that take into account feedback effects are known as dynamic scoring; Auerbach (2005). There are recent attempts to reconcile dynamic scoring with economic theory. For example, as stressed by Mankiw and Weinzierl (2005) and Leeper and Yang (2007), a tax cut can partially finance itself by generating economic growth and extending the tax base.

\section{Conclusion}

Robert Barro (2009) writes "There are reasons to think that the war-based multiplier of 0.8 substantially overstates the multiplier that applies to peacetime ......when I attempted to estimate directly the multiplier associated with peacetime government purchases, I got a number insignificantly different from zero". Paul Krugman (2008) writes "...I conclude that the stimulus package should be at least $4 \%$ of GDP".

These two quotes adumbrate the debate. No surprise, as it is reviewed in this essay. Empirics in imperfect accord steer competing economic models. Empirical and VAR techniques endeavour to clarify what an economic model should predict. These attempts are confronted with the difficult task of isolating the fiscal effect from other disturbances. The overall picture of the available evidence from VAR studies can be summarised as follows. Output increases following the expansionary fiscal shock; there are some exceptions though. The magnitude of the effect depends on the country under consideration and the sample period. This finding is consistent with the Keynesian and most DSGE models. Consumption increases in most studies particularly in those that tend to capture unanticipated shocks. Although this finding indicates a Keynesian effect, consumption decreases or shows no significant effect in empirical studies that tend to capture anticipated shocks in line with theories of forward looking behaviour. Furthermore, employment seems to increase following an expansionary fiscal shock. The reactions of the real wage and interest rate are not clear-cut making it difficult to draw support in favour or against a particular model. The real exchange rate depreciates following an expansionary fiscal shock in several studies contradicting Keynesian and standard DSGE models perditions. An expansionary fiscal shock has a negative effect on the trade balance and the current account in some studies while the effect is muted in others.

In the end, is a fiscal expansion effective in stimulating the economy? The answer is: "it depends". Notwithstanding mixed results, one may conclude that the there is no persuasive empirical evidence that fiscal stimuli harm the economy or a persuasive evidence on what would have happened without the fiscal expansion. After all, several results point to a stimulating effect of a fiscal expansion. However, one may also legitimately question the interpretation of the available results and stress the limitation in drawing unambiguous implications. In anticipation of the persuasive conclusion, the reader may ask himself am I Ricardian? And the investor may ask herself will a government fiscal expansion crowd out my investment? 


\section{References}

Adam, K. and Billi, R. (2008) Monetary conservatism and fiscal policy. Journal of Monetary Economics 55: 1376-88.

Auerbach, A. (2000) The significance of federal taxes as automatic stabilizers. Journal of Economic Perspectives 14: 37-56.

Auerbach, A. (2009) Long-term objectives for government debt. FinanzArchiv / Public Finance Analysis 65: 472-501.

Arin, P. K. and Koray, F. (2009) Beggar thy neighbour? the transmission of fiscal shocks from the US to Canada. Open Economies Review 20: 425-434.

Arin, P. K. and Koray, F. (2006) Are some taxes different than others? An empirical investigation of the effects of tax policy in Canada. Empirical Economics 31: 183-193.

Barro, R. (2009) Government spending is no free lunch. The Wall Street Journal, January 22, 2009.

Barry, F. and Devereux, M. (1995) The 'expansionary fiscal contraction hypothesis': a neo-Keynesian analysis. Oxford Economic Papers 27: 249-64.

Barry, F. and Devereux, M. (2003) Expansionary fiscal contraction: a theoretical exploration. Journal of Macroeconomics 25: 1-23.

Baxter, M. and King, R. (1993) Fiscal policy in general equilibrium. American Economic Review 83: 315-34.

Beetsma, R. and Jensen, H. (2005) Monetary and fiscal policy interactions in a micro-founded model of a monetary union. Journal of International Economics 67: 320-52.

Beetsma, R., Giuliodori, N. and Klaassen, F. (2006) Trade spill-over of fiscal policy in the European Union: a panel analysis. Economic Policy 21: 639-87.

Beetsma, R., Giuliodori, N. and Klaassen, F. (2008) The effects of public spending shocks on trade balances and budget deficits in the European Union. Journal of the European Economic Association 6: 414-23.

Bilbiie, F. (2008) Nonseparable preferences, fiscal policy puzzles and inferior goods. Journal of Money, Credit and Banking 41: 434-50.

Bilbiie, F., Meier, A. and Müller, G. (2008) What accounts for the changes in U.S. fiscal policy transmission?. Journal of Money Credit and Banking 40: 1439-1469.

Blanchard, O. and Perotti, R. (2002) An empirical characterization of the dynamic effects of changes in government spending and taxes on output. Quarterly Journal of Economics 117: 1329-68.

Blanchard, O. and Quah, D. (1989) The dynamic effects of aggregate demand and supply disturbances. American Economic Review 79: 655-73.

Bouakez, H. and Rebei, N. (2007) Why does private consumption rise after a government spending shock? Canadian Journal of Political Economy 40: 954-79.

Burnside, C., Eichenbaum, M. and Fisher, J. (2004) Fiscal shocks and their consequences. Journal of Economic Theory 115:89-117.

Campbell, J. and Mankiw, G. (1989) Consumption, income and interest rates: reinterpreting the time series evidence. NBER Macroeconomic Manual 1989: pp. 185-216.

Caldara, D. and Kamps, C. (2008) What are the effects of fiscal policy shocks? A VAR-based comparative analysis. European Central Bank Working Paper 877 (March).

Christiano, L. and Eichenbaum, M. (1992) Current real business cycles theories and aggregate labor market fluctuations. American Economic Review 82: 430-50.

Christiano, L. Eichenbaum, M. and Evans, C. L. (2005) Nominal rigidities and the dynamic effects of a shock to monetary policy. Journal of Political Economy, 113 (1):1-45.

Christiano, L. Eichenbaum, M. and Rebelo, S. (2009) When is the government spending multiplier large?. NBER Working Paper 15394.

Chung, H. and Leeper, E. (2007) What has financed government debt? Indiana University, mimeo.

Coenen, G. and Straub, R. (2005) Does government spending crowd in private consumption? Theory and empirical evidence for the euro area. International Finance 8: 435-70.

Cogan, J., Cwik, T. Taylor, J. and Wieland, V. (forthcoming) New Keynesian versus old Keynesian government spending multipliers. Journal of Economic Dynamics and Control.

Corsetti, G. and Müller, G. (2006) Twin deficits: squaring theory, evidence and common sense. Economic Policy 48: 597-638. 
Corsetti, G., Meier, A. and Müller, G. (2010) Cross-border spillovers from fiscal stimulus. International Journal of Central Banking 6: 5-37.

Corsetti, G., Meier, A. and Müller, G. (2009) Fiscal stimulus with spending reversals. International Monetary Fund Working Paper 09/106.

Cwik, T. and Wieland, V. (2009) Keynesian government spending multipliers and spillovers in the euro area. Goethe University Frankfurt, mimeo.

De Castro, F. and de Cos, P. (2008) The economic effects of fiscal policy: the case of Spain. Journal of Macroeconomics 30: 1005-1028.

DeJong, D. and Dave, C. (2007) Structural Macroeconometrics. Princeton University Press.

Dungey, M. and Fry, R.A. (2009) Identifying fiscal and monetary policy in a structural VAR. Economic Modelling 26: 1147-1160.

Edelberg, W., Eichenbaum, M. and Fisher, J. (1999) Understanding the effects of shocks to government purchases. Review of Economic Dynamics 2: 166-206.

Erceg, C., Guerrieri, L. and Gust, C. (2005) Expansionary fiscal shocks and the U.S. trade deficit. International Finance 8: 363-397.

Farmer, R. (forthcoming) How to Reduce Unemployment: a new policy proposal, Journal of Monetary Economics.

Faini, R. (2006) Fiscal policy and interest rates in Europe. Economic Policy 21: 444-489.

Fatás, A. and Mihov, I. (2001) The effects of fiscal policy on consumption and employment: theory and evidence. CEPR Discussion 2760.

Favero, C. and Giavazzi, F. (2009) How large are the effects of tax changes?. NBER Working Paper 15303.

Favero, C. and Giavazzi, F. (2007) Debt and the effect of fiscal policy. NBER Working Paper 12822.

Ferrero, A. (2009) Fiscal and monetary rules for a currency union. Journal of International Economics 77: $1-10$.

Forni, L., Monteforte., and L, Sessa, L. (2009) The general equilibrium effects of fiscal policy: Estimates for the Euro area. Journal of Public Economics 93: 559-585.

Fry, R. and Pagan, A. (2007) Some issues in using sign restrictions for identifying structural VARs. NCER Working Paper 14.

Galí, J. (2008) Monetary Policy, Inflation, and Business Cycle: An Introduction to the New Keynesian Framework. Princeton University Press.

Galí, J. and Monacelli, T. (2008) Optimal monetary and fiscal policy in a currency union. Journal of International Economics 76: 116-32.

Galí, J., López-Salido, J. D. and Vallés, J. (2007) Understanding the effects of government spending on consumption. Journal of the European Economic Association 5: 227-70.

Ganelli, G. (2005) The new open economy macroeconomics of government debt. Journal of International Economics 22: 87-103.

Ganelli, G. (2007) The effects of fiscal shocks on consumption: reconciling theory and data. The Manchester School 75: 193-209.

Giordano, R., Momigliano, S. Neri, S., and Perotti, R. (2007) The effects of fiscal policy in Italy: estimates from a VAR model. European Journal of Political Economy 23: 707-733.

Hebous, S. and Zimmermann, T. (2010) Budget deficit spillover effects in the Euro Area. Goethe University Frankfurt, mimeo.

Henry, J., de Cos, P., and Momigliano, S. (2008) The impact of government budgets on prices: evidence from microeconometric models. Journal of Policy Modelling 30: 123-143.

Hemming, R., Kell, M. and Mahfouz, S. (2002) The effectiveness of fiscal policy in stimulating economic activity- a review of the literature. International Monetary Fund Working Paper $02 / 208$.

Heppke-Falk, K., Tenhofen, J., and Wolff, G. (2006) The macroeconomic effects of exogenous fiscal policy shocks in Germany: a disaggregated analysis. Deutsche Bundesbank Discussion Paper 41.

IMF Staff Position Note (2008) Fiscal policy for the crisis. SPN/08/01.

IMF Staff Position Note (2009) Fiscal implications of the global economic and financial crisis. SPN/09/13.

Kim, S. and Roubini, N. (2008) Twin deficit or twin divergence? Fiscal policy, current account, and real exchange rate in the U.S. Journal of International Economics 74: 362-83. 
Kneller, R, Bleaney, F. M., and Gemmell, N. (1998) Fiscal policy and growth: evidence from OECD countries. Journal of Public Economics 74: 171-190.

Krugman, P. (2008) The conscience of a liberal. The New York Times, June 12, 2008.

Lane, P. and Perotti, R. (1998) The trade balance and fiscal policy in the OECD. European Economic Review 42: 887-895.

Laubach, T. (2007) New evidence on interest rate effects of budget deficits and debt. Journal of the European Economic Association 7: 858-85.

Leeper, E. and Yang, S. (2008) Dynamic scoring: alternative financing schemes. Journal of Public Economics 92: 159-82.

Linnemann, L. (2006) The effects of government spending on private consumption: a puzzle? Journal of Money, Credit and Banking 38: 1715-35.

Linnemann, L. and Schabert, A. (2003) Fiscal policy in the new neoclassical synthesis. Journal of Money, Credit and Banking 35: 911-29.

Lütkepohl, L. (2005) New Introduction to Multiple Time Series Analysis. Berlin: Springer.

Mankiw, G. (2000) The savers-spenders theory of fiscal policy. American Economic Review 90: 120125.

Mankiw, G. and Weinzierl, M. (2006) Dynamic scoring: a back-of-the-envelope guide. Journal of Public Economics 90: 1415-33.

McCandless, G. (2008) The ABCs of RBCs - An Introduction to Dynamic Macroeconomic Models. Harvard University Press.

Mertens, K. and Ravn, M. (2009) Understanding the aggregate effects of anticipated and unanticipated tax policy shocks. EUI, mimeo.

Monacelli, T. and Perotti, R. (2008) Openness and the sectoral effects of fiscal policy. Journal of the European Economic Association 6: 395-403.

Monacelli, T. and Perotti, R. (forthcoming) Fiscal policy, the real exchange rate, and traded goods. Economic Journal.

Mountford, A. and Uhlig, H. (2009) What are the effects of fiscal policy shocks?. Journal of Applied Econometrics 24: 960-992.

Müller, G. (2008) Understanding the dynamic effects of government spending on foreign trade. Journal of International Money and Finance 27: 345-71.

Obstfeld, M. and Rogoff, K. (1995) Exchange rate dynamic Redux. Journal of Political Economy 103: 624-660.

Pappa, E. (2009a) The effects of fiscal shocks on employment and real wages. International Economic Review 50: 217-44.

Pappa, E. (2009b) The effects of fiscal expansions: an international comparison. Universitat Autònoma de Barcelona, mimeo.

Paustian, M. (2007) Assessing sign restrictions. The B.E. Journal of Macroeconomics 7: 1-31.

Perotti, R. (2005) Estimating the effect of fiscal policy in OECD countries. Proceedings, Federal Reserve Bank of San Francisco.

Perotti, R. (2007) In search of the transmission mechanism of fiscal policy. NBER Macroeconomic Manual 200722.

Pesaran, H., Schuermann, T. and Weiner, S. (2004) Modelling regional interdependencies using a global error-correcting macroeconometric model. Journal of Business and Economic Statistics 22: $129-62$.

Ramey, A. (2008) Identifying government spending shocks: it's all in the timing. UCSD, mimeo.

Ramey, A. and Shapiro, M.D. (1998) Costly capital reallocation and the effects of government spending. Carnegie-Rochester Conference Series on Public Policy 48: 145-194.

Ravn, M., Schmitt-Grohé, S. and Uribe, M. (2006) Deep habits. Review of Economic Studies 73: 195218.

Ravn, M., Schmitt-Grohé, S. and Uribe, M. (2007) Examining the effects of government spending shocks on consumption and the real exchange rate. Duke University mimeo.

Ravn, M., Schmitt-Grohé, S. and Uribe, M. (2008) Habit persistence. In (2 ${ }^{\text {nd }}$ ed.) New Palgrave Dictionary of Economics.

Rebelo, S. (2005) Real business cycle models: past, present and future. Scandinavian Journal of Economics 107: 217-38. 
Romer, C. and Romer, D. (forthcoming) The macroeconomic effects of tax changes: estimates based on a new measure of fiscal shocks. American Economic Review.

Schmitt-Grohé, S. and Uribe, M. (2007) Optimal, simple and implementable monetary and fiscal rules. Journal of Monetary Economics 54: 1702-25.

Sims, C.A. (1980) Macroeconomics and reality. Econometrica 48: 1-48.

Smets, F. and Wouters, R. (2003) An estimated stochastic dynamic general equilibrium model of the euro area. Journal of the European Economic Association 1: 1123-1501.

Stock, J. and Watson, M. (2001) Vector autoregressions. Journal of Economic Perspectives 15: 101-15.

Sutherland, A. (1997) Fiscal crises and aggregate demand: can high public debt reverse the effects of fiscal policy?. Journal of Public Economics 65: 147-162.

Taylor, J. (2000) The reassessing discretionary fiscal policy. Journal of Economic Perspectives 14: 2136.

Tenhofen, J. and Wolff, G. (2007) Does anticipation of government spending matter? Evidence from an expectation augmented VAR. Deutsche Bundesbank Discussion Paper 14.

Uctum, M. and Wickens, M. (2000) Debt and deficit ceilings, and sustainability of fiscal policies: an intertemporal analysis. Oxford Bulletin of Economics and Statistics 62: 197-222.

Uhlig, H. (2005) What are the effects of monetary policy? Results from an agnostic identification procedure. Journal of Monetary Economics 52: 381-419.

Uhlig, H. (2009) Some Fiscal Calculus. University of Chicago, mimeo.

Van den Noord, P. (2000) The size and the role of automatic fiscal stabilizers in the 1990s and beyond. OECD Economics Department Working Paper 230.

Wickens, M. (2008) Macroeconomic Theory: A Dynamic General Equilibrium Approach. Princeton University Press.

Woodford, M. (2003) Interest and Prices: Foundation of a Theory of Monetary Policy. Princeton University Press.

Zubairy, S. (2009) Explaining the effects of government spending shocks. Duke University, mimeo. 